\title{
Assessment of Water Resources in Nagarjuna Sagar Right Canal (Jawahar) Command of Andhra Pradesh
}

\author{
D. Sai Gangadhara Rao ${ }^{1 *}$, H. V. Hema Kumar ${ }^{1}$, B. Sarojini Devi ${ }^{2}$, \\ L. Edukondalu ${ }^{3}$ and V. Srinivasa Rao ${ }^{4}$
}

\author{
${ }^{1}$ Department of Soil and Water Engineering, Dr NTR CAE, Bapatla, India \\ ${ }^{2}$ Department of Agricultural Engineering, Agricultural College, Mahanandi, India \\ ${ }^{3}$ Department. of Agricultural Processing and Food Engineering, CFST, Pulivendula, India \\ ${ }^{4}$ Department of Statistics \& Computer Applications, Agricultural, College, Bapatla, India
}

*Corresponding author

\section{A B S T R A C T}

\begin{tabular}{|l|}
\hline Ke y w o r d s \\
NSPRCC, \\
Hydraulic \\
particulars, \\
Discharge, \\
Groundwater, \\
Surface water
\end{tabular}

The Nagarjuna Sagar Project is one of the prestigious projects in India and it irrigates nearly 9 lakhs ha area.The canal is divided into 9 branch canals spread across Guntur and Prakasam districts. The month wise and branch wise discharge data and hydraulic particulars of main and branch canal was collected from Water Resources Department, Lingamguntla circle and Ongole circle. The daily rainfall data from 1997 to 2018 (22 years) obtained from the Directorate of Economics and Statistics (DES) was used for calculating annual availability of rainfall distribution over the command area. The total availability of the surface water of 11 years was is 2,229 MCM. Average annual rainfall of Guntur and Prakasam Districts under command area was noticed as 780 $\mathrm{mm}$ and 749 and overall command area was recorded as $765 \mathrm{~mm}$. The average groundwater availability of the command area was estimated as $1385 \mathrm{MCM}$. Finally, conjunctive use of water in command area is 3,614 MCM (128 TMC).

\section{Introduction}

The Nagarjuna Sagar Project is built across river Krishna at Nandikonda village of Nalgonda District. The main objective of this Nagarjuna Sagar project is to bring the 9 lakhs hectare of land under cultivation. The right canal was designed with carrying capacity of 11,000 Cusecs. The area irrigated by Nagarjuna Sagar Jawahar Canal is about
4.75 lakhs ha in Guntur and Prakasam districts (Anonymous, 1999).

The Canal is divided into 9 branch canals spread across Guntur and Prakasam districts. The Right main canal having Guntur, Zulakallu, Bellarnkonda, Peddanandipadu, Addanki, Eddanapudi, Darsi, Pamidipadu and Ongole branch canals. 


\section{Study area}

\section{Nagarjuna Sagar Project Right Canal (Jawahar) Command}

The command area lies between the latitudes of $15^{\circ} 20^{\prime} 00^{\prime \prime}$ to $16^{\circ} 41^{\prime} 24^{\prime \prime} \mathrm{N}$ and the longitudes of $79^{\circ} 18^{\prime} 44^{\prime \prime}$ to $80^{\circ} 25^{\prime} 56^{\prime \prime} \mathrm{E}$, encompassing Guntur and Prakasam districts in the state of Andhra Pradesh. The geographical command area consists from block 1 to 22 (GA) as shown in Figure 1 and Table 1.

Nagarjuna Sagar Right (Jawahar) Canal Command area spreads over 37 mandals in Guntur and 23 mandals in Prakasam districts.

\section{Materials and Methods}

\section{Surface water availability}

Nagarjuna Sagar Right (Jawahar) Canal water releases data i.e. month wise and branch wise discharge data and hydraulic particulars of main and branch canal was collected from Water resources department, Lingamguntla circle and Ongole circle for a period from 2008 to 2018. Mean annual availability of water at different stages was computed. The daily rainfall data from 1997 to 2018 (22 years) was obtained from the Directorate of Economics and Statistics (DES) and used for calculating annual availability of rainfall contribution over the command area by Usman et al., (2016).

\section{Groundwater monitoring}

Groundwater monitoring is being carried-out continuously by monitoring of 300 observation wells in Nagarjuna Sagar Right Canal command area comprising I to XXII blocks with 188 Observation wells in Guntur and 112 Observation wells in Prakasam established the State Groundwater Department. Usman et al (2016) studied variations in conjunctive water management practices, groundwater productivity and crop profitability in Chuharkana irrigation subdivision.

\section{Assessment of ground water resources using water table fluctuation method}

Water Table Fluctuation (WTF) method is based on the premise that rise in groundwater levels in unconfined aquifers are due to recharge water arriving at the water table. It is the most widely used method for estimating recharge (Healy and Cook, 2002).

Recharge is calculated as

$\mathrm{R}=\mathrm{S}_{\mathrm{y}} \mathrm{dh} / \mathrm{dt}$

Where

$\mathrm{R}$ recharge, $\mathrm{S}_{\mathrm{y}}$ the specific yield, $\mathrm{h}$ is watertable height, and $t$ is time

Static ground water reserve $=$ thickness of aquifer below the zone of water level fluctuation down to exploitable limit Average DTW $X$ areal extent of the aquifer $X$ specific yield of the aquifer

Water Table Fluctuations represent spatially averaged recharge. Determining representative values of $S_{y}$ is a major difficulty in applying this method. Another difficulty lies in ensuring that the fluctuations in water levels are due to recharge and are not the result of changes in atmospheric pressure, the presence of entrapped air or other phenomena such as pumping.

\section{Results and Discussion}

The surface water availability estimated from different sources namely water releases data obtained by Water Resources Department, Lingamguntla and Ongole Circles of Nagarjuna Sagar Right Canal (Jawahar) Command Area, Andhra Pradesh is presented in Figure 2. 
Table.1 Line diagram of Nagarjuna Sagar Right Main Canal

\begin{tabular}{|c|c|c|c|c|c|}
\hline Milage & \multirow{37}{*}{ 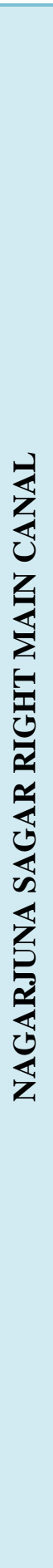 } & $\begin{array}{c}\text { Name of the Branch Canal/ } \\
\text { Major }\end{array}$ & Length & $\begin{array}{l}\text { Designed } \\
\text { discharge }\end{array}$ & Block No \\
\hline M-F-Ft & & & M-F-Ft & in $\mathrm{C} / \mathrm{S}$ & \\
\hline 0-0-000 & & Right Canal Head Regulator & & 11,000 & \\
\hline 4-6-000 & & Pasuvemula Major & $1-0-207$ & 5.24 & 1 \\
\hline 7-0-000 & & Tallapalli Major - I & $0-4-365$ & 4.48 & 2 \\
\hline 8-4-000 & & Tallapalli Major - II & $0-4-300$ & 10.13 & 2 \\
\hline 12-1-558 & & Mallavaram Major & $7-7-572$ & 126.18 & 3 \\
\hline 13-6-000 & & Khambampadu Major & $1-6-290$ & 18.53 & 3 \\
\hline 15-7-000 & & Paluvai Major & $5-0-110$ & 64.09 & 3 \\
\hline 20-7-076 & & Buggavagu O T Regulator & & 11000 & \\
\hline 21-7-00 & & Rentachintala Major & $9-5-655$ & 42.64 & 4 \\
\hline 24-0-110 & & Daida Major & $12-6-360$ & 266.40 & 4 \\
\hline 24-6-440 & & Charlagudipadu Major & $3-4-150$ & 24.16 & 4 \\
\hline 27-3-550 & & Miryala Major & $2-5-495$ & 17.20 & 5 \\
\hline $30-2-220$ & & Ramapuram Major & $18-3-018$ & 253.80 & 5 \\
\hline 33-4-000 & & Pedakodamagundla Major & $2-4-402$ & 22.30 & 5 \\
\hline $34-2-655$ & & $\begin{array}{l}\text { Cross regulator cum surplus } \\
\text { escape }\end{array}$ & & 10100 & \\
\hline 38-0-330 & & Kesanupalli Major & $6-6-613$ & 68.80 & 6 \\
\hline 40-4-280 & & Zulakallu Branch Canal & $1-3-299$ & 564.29 & 6 \\
\hline $42-0-560$ & & Janapadu Major & $4-4-000$ & 34.40 & 6 \\
\hline 46-3-000 & & Guttikonda Major & $2-4-535$ & 15.20 & 7 \\
\hline 47-3-550 & & Kotanemalipuri Major & $7-2-330$ & 31.40 & 7 \\
\hline 49-5-570 & & Bellamkonda Branch Canal & $11-3-027$ & 645 & $8 \& 9$ \\
\hline $52-5-165$ & & Guntur Branch Canal & $32-1-000$ & 2920 & 10 \\
\hline $52-7-400$ & & $\begin{array}{l}\text { O.T. of } 1 \text { AR Kothapalli } \\
\text { Major(shifted from GBC) }\end{array}$ & & 8.64 & 10 \\
\hline $57-0-475$ & & Addanki Brach Canal & $37-3-272$ & 2469 & 11 \\
\hline $57-2-250$ & & Cross regulator & & 3947.00 & \\
\hline $58-6-543$ & & Inumella D.P & & $1.07 / 0.25$ & $11 \mathrm{~A}$ \\
\hline $59-5-300$ & & Inumella Major & $8-0-080$ & 23.20 & $11 \mathrm{~A}$ \\
\hline 64-2-330 & & Ipur D.P & & 1.80 & 12 \\
\hline 66-0-610 & & Angaluru Major & $8-0-440$ & 52.02 & 12 \\
\hline 69-6-049 & & Perumallapalli Major & $20-5-372$ & 192.60 & 13 \\
\hline 74-0-470 & & Perurupadu Major & $3-1-110$ & 28.97 & 13 \\
\hline 78-3-196 & & Dondapadu Major & $6-2-220$ & 48.97 & 14 \\
\hline $81-5-474$ & & Cheekateegalapalem Major & $14-1-550$ & 140.14 & 14 \\
\hline $83-2-402$ & & Palakuru Major & $0-6-250$ & 5.57 & 14 \\
\hline 85-3-150 & & Cross regulator cum escape & & 3346 & \\
\hline
\end{tabular}


Table.2 Annual average rainfall data of NSP right canal command from 1997-2018

\begin{tabular}{|c|c|c|c|}
\hline Year & $\begin{array}{c}\text { Average Guntur } \\
\text { rainfall, mm }\end{array}$ & $\begin{array}{c}\text { Average Prakasam } \\
\text { rainfall, } \mathbf{~ m}\end{array}$ & $\begin{array}{c}\text { Average command area } \\
\text { rainfall, } \mathbf{~ m m}\end{array}$ \\
\hline $\mathbf{1 9 9 7}$ & 812.79 & 995.02 & 903.91 \\
\hline $\mathbf{1 9 9 8}$ & 897.25 & 881.50 & 889.38 \\
\hline $\mathbf{1 9 9 9}$ & 590.66 & 526.55 & 558.61 \\
\hline $\mathbf{2 0 0 0}$ & 914.58 & 865.98 & 890.28 \\
\hline $\mathbf{2 0 0 1}$ & 809.20 & 737.07 & 773.14 \\
\hline $\mathbf{2 0 0 2}$ & 533.01 & 500.20 & 516.61 \\
\hline $\mathbf{2 0 0 3}$ & 862.92 & 684.30 & 773.61 \\
\hline $\mathbf{2 0 0 4}$ & 739.67 & 578.63 & 659.15 \\
\hline $\mathbf{2 0 0 5}$ & 896.35 & 789.69 & 843.02 \\
\hline $\mathbf{2 0 0 6}$ & 724.28 & 827.79 & 776.04 \\
\hline $\mathbf{2 0 0 7}$ & 915.52 & 848.51 & 882.02 \\
\hline $\mathbf{2 0 0 8}$ & 911.43 & 921.96 & 916.70 \\
\hline $\mathbf{2 0 0 9}$ & 395.00 & 542.70 & 468.85 \\
\hline $\mathbf{2 0 1 0}$ & 1344.15 & 1458.24 & 1401.20 \\
\hline $\mathbf{2 0 1 1}$ & 625.26 & 524.70 & 574.98 \\
\hline $\mathbf{2 0 1 2}$ & 960.14 & 957.30 & 958.72 \\
\hline $\mathbf{2 0 1 3}$ & 111.02 & 1085.85 & 1098.44 \\
\hline $\mathbf{2 0 1 4}$ & 603.13 & 452.79 & 527.96 \\
\hline $\mathbf{2 0 1 5}$ & 606.63 & 674.85 & 640.74 \\
\hline $\mathbf{2 0 1 6}$ & 796.93 & 590.23 & 693.58 \\
\hline $\mathbf{2 0 1 7}$ & 650.56 & 651.55 & 651.06 \\
\hline $\mathbf{2 0 1 8}$ & 464.34 & 389.95 & 427.15 \\
\hline $\mathbf{A v e r a g e}$ & $\mathbf{7 8 0 . 2 2}$ & $\mathbf{7 4 9 . 3 3}$ & $\mathbf{7 6 4 . 7 8}$ \\
\hline & & & \\
\hline & & & \\
\hline
\end{tabular}

Table.3 Annual average groundwater availability in NSRC command area

\begin{tabular}{|c|c|c|c|}
\hline Year & $\begin{array}{c}\text { Static Available } \\
\text { Ground water } \\
\text { resources (ha-m) }\end{array}$ & $\begin{array}{c}\text { Static Available } \\
\text { Ground water } \\
\text { resources (MCM) }\end{array}$ & $\begin{array}{c}\text { Static Available } \\
\text { Ground water } \\
\text { resources (TMC) }\end{array}$ \\
\hline $\mathbf{2 0 0 8 - 0 9}$ & 306220.56 & 3062.21 & 108.14 \\
\hline $\mathbf{2 0 0 9 - 1 0}$ & 231930.37 & 2319.30 & 81.91 \\
\hline $\mathbf{2 0 1 0 - 1 1}$ & 241896.13 & 2418.96 & 85.43 \\
\hline $\mathbf{2 0 1 1 - 1 2}$ & 231477.38 & 2314.77 & 81.75 \\
\hline $\mathbf{2 0 1 2 - 1 3}$ & 204298.04 & 2042.98 & 72.15 \\
\hline $\mathbf{2 0 1 3 - 1 4}$ & 231477.38 & 2314.77 & 81.75 \\
\hline $\mathbf{2 0 1 4 - 1 5}$ & 211998.85 & 2119.99 & 74.87 \\
\hline $\mathbf{2 0 1 5 - 1 6}$ & 182554.57 & 1825.55 & 64.47 \\
\hline $\mathbf{2 0 1 6 - 1 7}$ & 199768.15 & 1997.68 & 70.55 \\
\hline $\mathbf{2 0 1 7 - 1 8}$ & 231024.39 & 2310.24 & 81.59 \\
\hline $\mathbf{2 0 1 8 - 1 9}$ & 224229.56 & 2242.30 & 79.19 \\
\hline volume & $\mathbf{2 2 6 9 8 8 . 6 7}$ & $\mathbf{2 2 6 9 . 8 9}$ & $\mathbf{8 0 . 1 6}$ \\
\hline
\end{tabular}


Fig.1 Location map of the study area

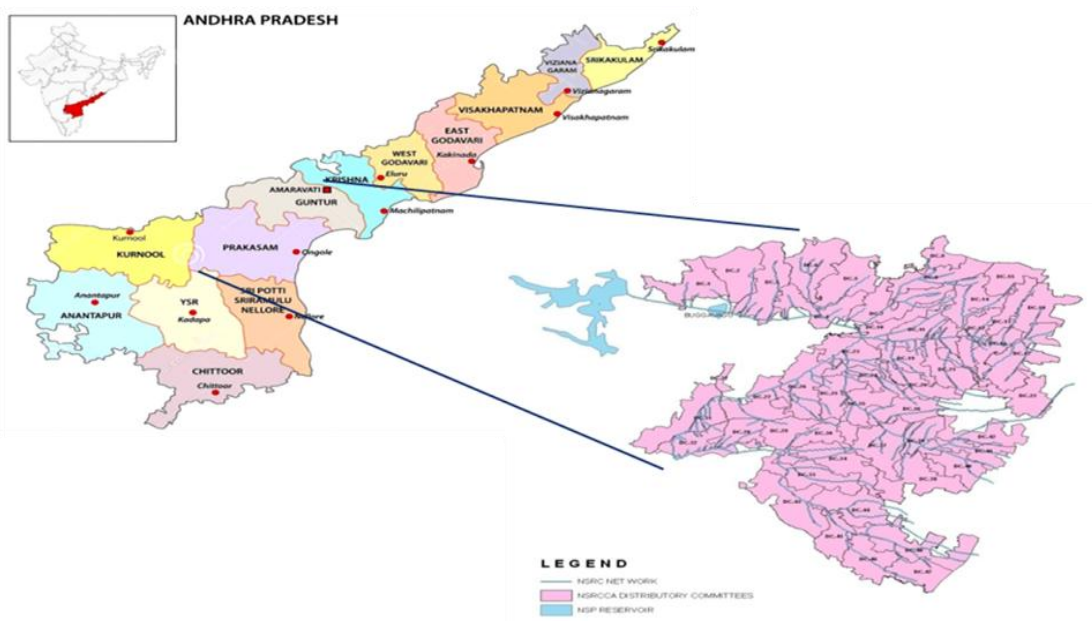

Fig.2 Off-take wise water withdrawals of NSP right canal command area at different levels (TMC)

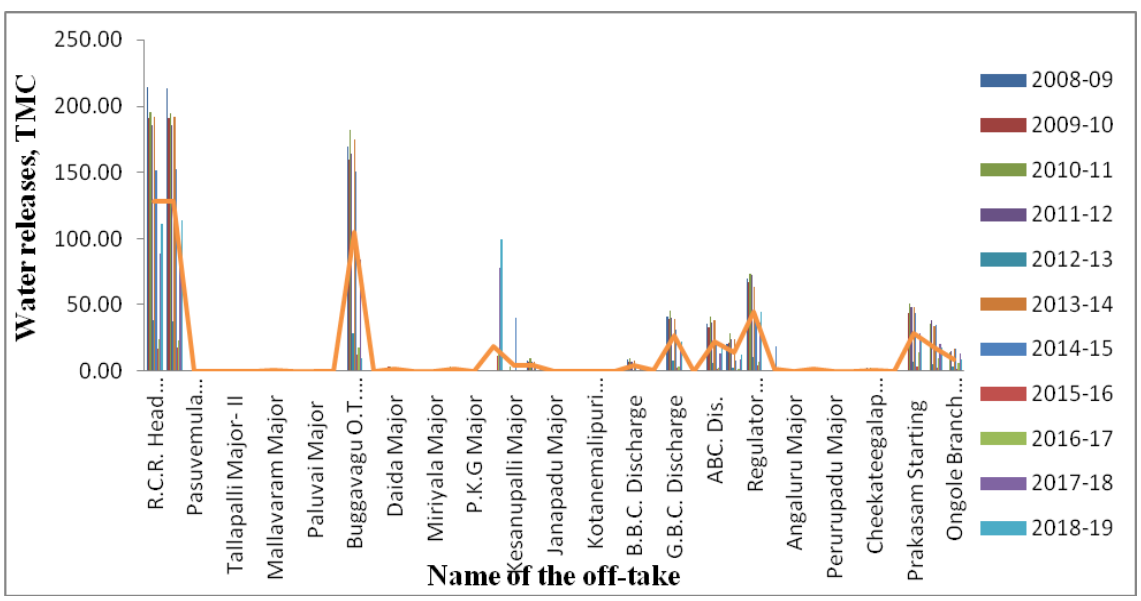

Fig.3 Average annual rainfall of the command area from 2008-2018

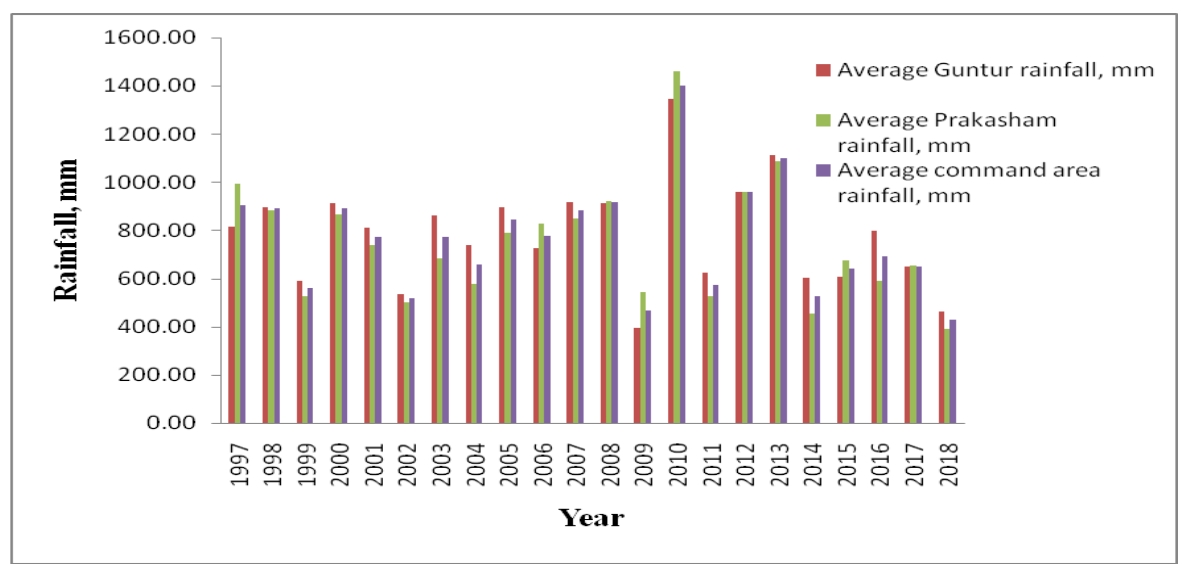


Fig.4 Network of Observation wells in Nagarjuna Sagar Right (Jawahar) canal command area

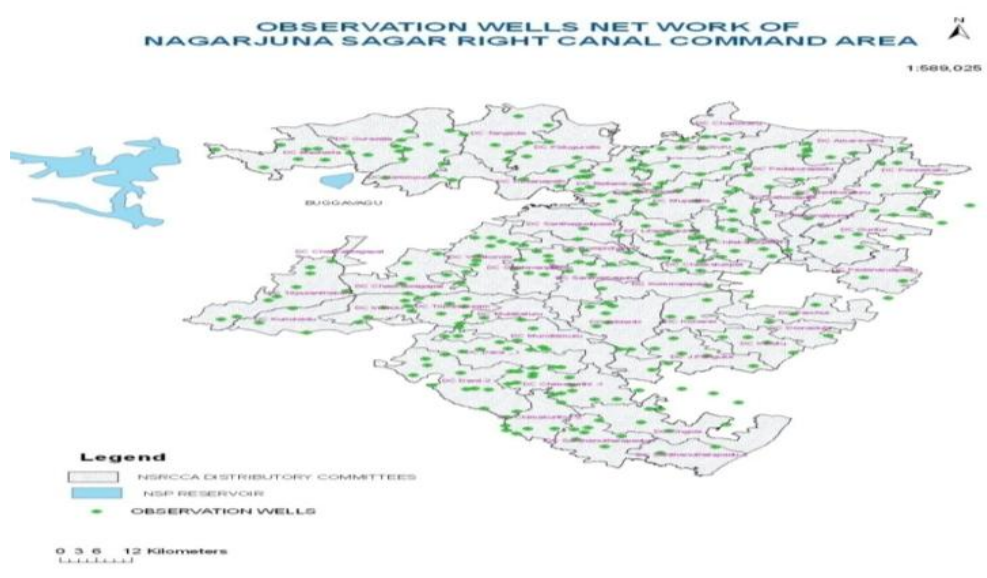

Fig.5 Average station wise depth to water level of observation wells BGL in Nagarjuna Sagar right canal command area from 2000 to 2018

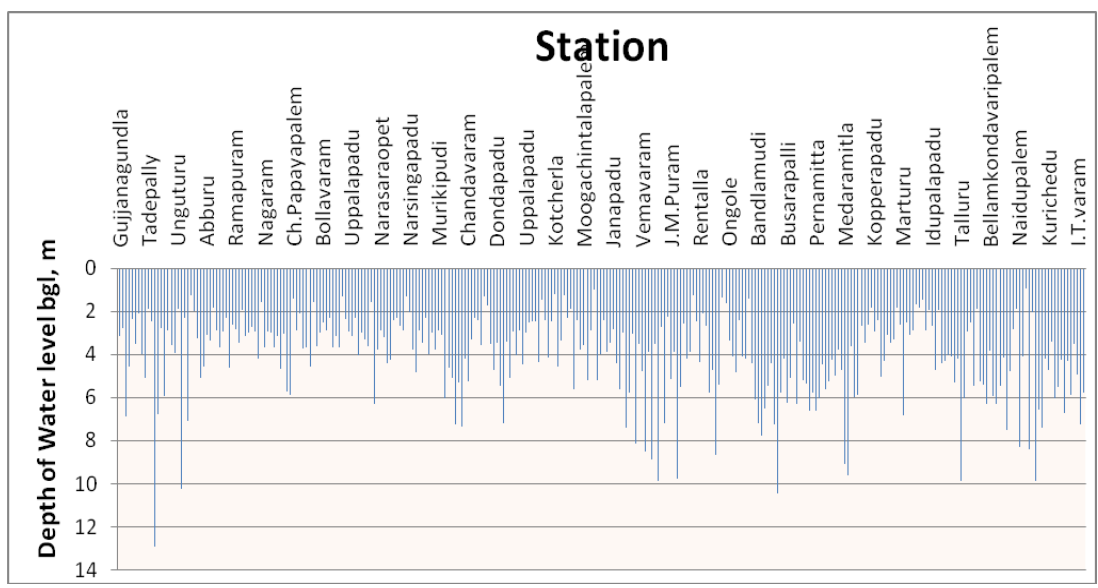

Fig.6 Average Station wise depth to water levels of Piezometers BGL in Nagarjuna Sagar right canal command area from 2016 to 2018

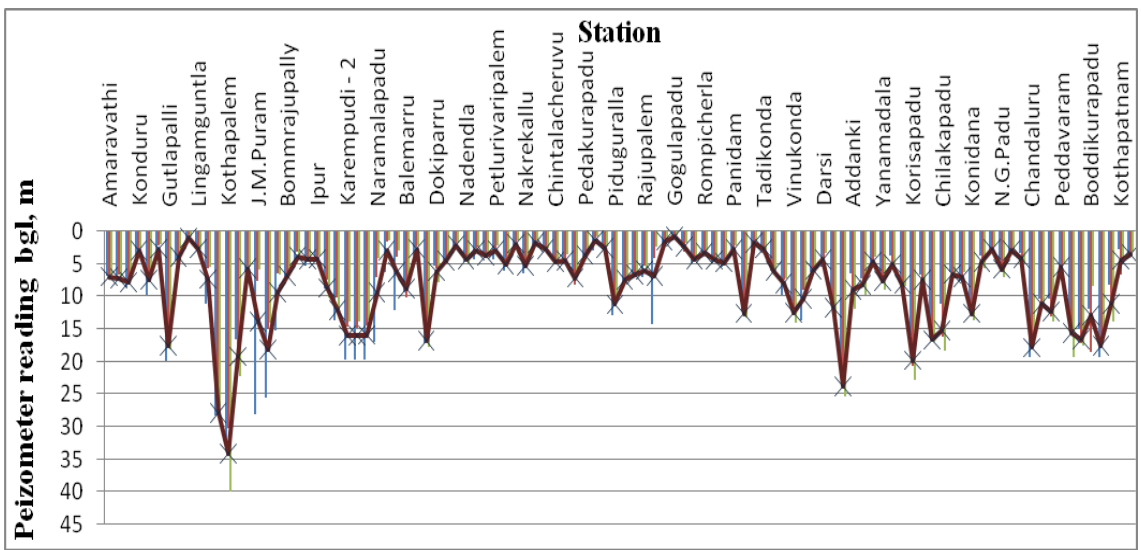


Fig.7 Mean monthly 300 observation wells readings from 2000 to 2018

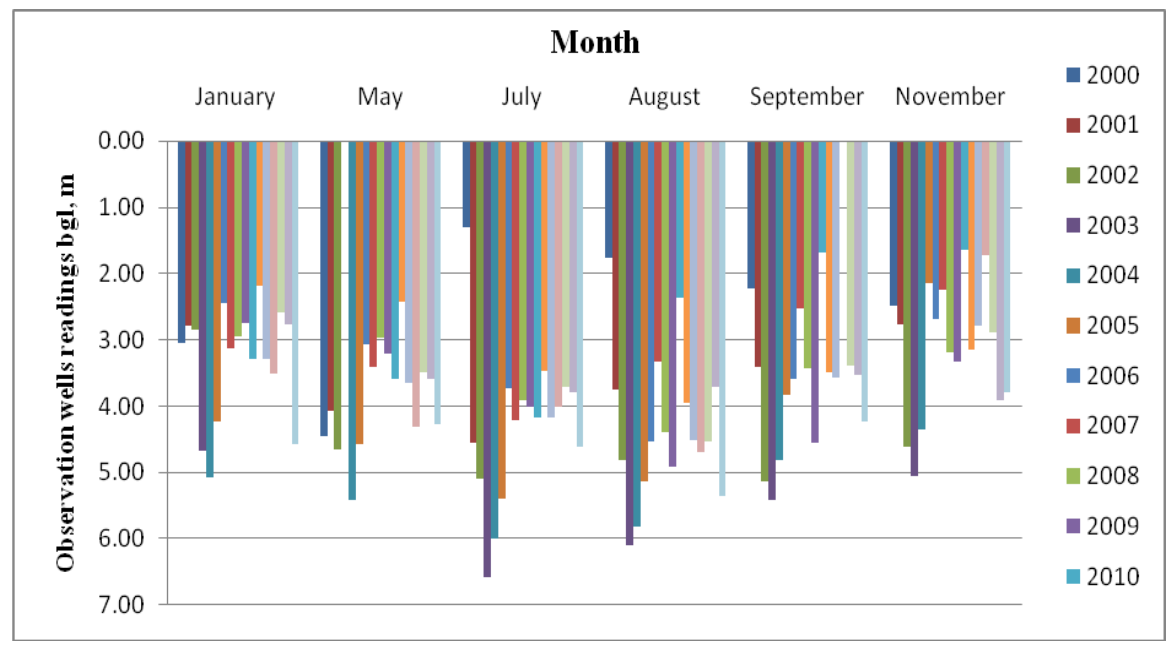

From the above data, off-take wise water withdrawals of the entire command from the year 2008-09 to 2018-19 were computed. The mean withdrawal of water releases off-take wise was computed and maximum obtained at Buggavagu O.T. with 104.92 TMC and minimum value was obtained at Pasuvemula Major and Tallapalli Major- I with 0.03 TMC. The mean water releases at head section of 11 years of data was computed as 128.13 TMC $(3,627.71 \mathrm{MCM})$.

The evaporation losses take place from the exposed water surface area, which would vary with the temperature, humidity, wind velocity etc. In hot and dry weather months (summer) these losses are maximum but they seldom exceed $1-2 \%$ of the total water entering into the canal. The average evaporation varies between $4 \mathrm{~mm}$ to $10 \mathrm{~mm}$ per day. The conveyance losses now evaluated in the canals selected are inclusive of evaporation losses and no separate studies could be possible.

The overall conveyance efficiency of the Nagarjuna Right Bank Canal (including evaporation losses and seepage losses etc.,) as $61.45 \%$ recommended by the CWC, Government of India and then total availability of the surface water is 2,229 MCM.

\section{Rainfall}

Mean annual rainfall entire command area comprises of two districts namely Guntur and Prakasam as shown in Table 2 and Figure 3.

From the above data average annual rainfall of Guntur and Prakasam Districts under command area was noticed as $780 \mathrm{~mm}$ and $749 \mathrm{~mm}$ and overall command area was recorded as $765 \mathrm{~mm}$.

\section{Groundwater availability}

Groundwater monitoring is being carried out in both districts of Andhra Pradesh by the State Groundwater Department. The observation wells network in Nagrajuna Sagar Right (Jawahar) Canal Command Area was shown in Fig. 4.

The location wise 300 mean observation wells from year 2000 to 2018 reading was shown in Figure 5. From the data maximum value was observed as $12.96 \mathrm{~m}$ below ground level at Mothadaka village and minimum value obtained was $0.934 \mathrm{~m}$ below ground level at 
Brundavanam village. Mothadaka village in Tadikonda Mandal in Guntur District was more groundwater table as compared to the Brundavanam village in Sattenapally Guntur District (Table 3).

\section{Piezometer}

AP State Groundwater Department was installed 104 piezometers in the command area the reading was presented Figure 6. From the above data, the maximum reading was obtained as $23.75 \mathrm{~m}$ DTW at Tallur and minimum value obtained as $0.87 \mathrm{~m}$ DTW at Gogulapadu Village, Gurazala mandal, Guntur district. The data revealed that the groundwater depletion was more at Tallur compared to Gogulapadu Village, Gurazala mandal, Guntur district.

From the above data highest value $6.59 \mathrm{~m}$ in the month of July, 2003 and minimum value occurred in the month of September, 2013 due highest rainfall and canal release during the above period.

Groundwater volume data was collected from the State Groundwater Department, Guntur and presented in the Table 3.

From the data, it was clear that, the maximum value was observed as $3062.21 \mathrm{MCM}$ in the year 2008-09 and minimum value in the year 2015-16 as 1825.55 MCM. i.e. due to poor rainfall and overdraft of ground water. Average groundwater availability was 2270 MCM (80.16 TMC). Finally the groundwater availability is $61 \%$ of $2270 \mathrm{MCM}$ and total availability of the surface water is 2,229 MCM. The available water resources for conjunctive use in the command area are 3,614 MCM (128 TMC) (Fig. 7).

In conclusions the Nagarjuna Sagar Right Canal Command area of the total availability of the surface water of 11 years of data was is
2,229 MCM. Average annual rainfall of Guntur and Prakasam Districts under command area was obtained as $780 \mathrm{~mm}$ and 749 and overall command area was recorded as $765 \mathrm{~mm}$. The average groundwater availability in the command area is 1385 MCM. Finally, the total water available by conjunctive use in the command area is 3,614 MCM (128 TMC).

\section{Acknowledgement}

We acknowledged the Acharya N G Ranga Agricultural University, Lam, Guntur for financial and technical support for successful completion research.

\section{References}

Anonymous, 1999., Study of waterlogging in five canal commands. Nagarjuna Sagar right bank canal command area (Andhra Pradesh). (6):1-93.

Anonymous, 2016., Performance Overview and Management Improvement Organization Central Water Commission Government of India. Report on Summary Report on Water use Efficiency Studies for 35 Irrigation Projects. Pp. 45-48.

Healy, R.W., and Cook, P.G. 2002. Using groundwater levels to estimate recharge. Hydrogeology Journal. 10:91-109.

Mohammad, K., Z. Banafsheh, K. Reza and Ahmad, E. 2008. Crop pattern and conjunctive use management: A case study. Journal of Irrigation and Drainage Engineering. 59: 161-173.

Prasad, A., N.V. Umamahesh and Viswanath, G. K. 2006. Optimal irrigation planning under water scarcity. Journal of Irrigation and Drainage Engineering. 132(3): 228-237.

Sanjeev, R., R.K. Jaiswal and Galakte, R.V. 2011. Estimation of surface and ground water resources in Sagar, Madhya 
Pradesh, India. Journal of Environmental Research and Development. 5(3A): 823829.

Sudhakar, P., and Abhishek, S. 2017. Conjunctive use and management of surface and groundwater resources as part of integrated river basin management. International Journal of Engineering Technology Science and
Research. 4(8): 907-911.

Usman, M., A. Abbas and Saqib, Z.A. 2016. Conjunctive use of water and its management for enhanced productivity of major crops across tertiary canal irrigation system of Indus basin in Pakistan. Pakistan Journal of Agricultural Science. 53(1): 257-264.

\section{How to cite this article:}

Sai Gangadhara Rao, D., H. V. Hema Kumar, B. Sarojini Devi, L. Edukondalu and Srinivasa Rao, V. 2020. Assessment of Water Resources in Nagarjuna Sagar Right Canal (Jawahar) Command of Andhra Pradesh. Int.J.Curr.Microbiol.App.Sci. 9(10): 2437-2445. doi: https://doi.org/10.20546/ijcmas.2020.910.291 